CASE REPORT

\title{
Familial isolated hyperparathyroidism due to multiple adenomas associated with ossifying jaw fibroma and multiple uterine adenomyomatous polyps
}

\author{
Megumi Fujikawa, Ken Okamura, Kaori Sato, Tetsuya Mizokami, Kinya Tamaki ${ }^{1}$, Tomoko Yanagida ${ }^{1}$ and \\ Masatoshi Fujishima \\ Second Department of Internal Medicine, Kyushu University and ${ }^{1}$ Kyushu Chuo Hospital, Fukuoka, Japan \\ (Correspondence should be addressed to M Fujikawa, Second Department of Internal Medicine, Faculty of Medicine, Kyushu University, \\ Maidashi 3-1-1, Higashi-ku, Fukuoka City 812-82, Japan)
}

\begin{abstract}
We describe three siblings with hyperparathyroidism due to multiple parathyroid adenomas without evidence of other endocrinological abnormalities. A 22-year-old woman had two parathyroid adenomas complicated by multiple ossifying jaw fibromas. Her sister, aged 29, also suffered from primary hyperparathyroidism associated with two parathyroid adenomas one of which was also suspected to be a carcinoma. These two female patients had unusual multiple small uterine polyps, which were diagnosed as adenomyomatous polyps. Their brother, aged 17, had two parathyroid adenomas complicated by urolithiasis. These three patients are characterized by young adult-onset familial isolated hyperparathyroidism due to multiple adenomas with various complications including ossifying jaw fibroma and uterine adenomyomatous polyps. These clinical features are different from those of familial hyperparathyroidism associated with multiple endocrine neoplasia.
\end{abstract}

European Journal of Endocrinology 138 557-561

\section{Introduction}

Familial isolated hyperparathyroidism (FIHP) is a rare hereditable disorder characterized by hypercalcemia, inappropriately high parathyroid hormone (PTH), and isolated parathyroid tumors with no evidence of hyperfunction of any other endocrine tissues (1). Unusual jaw lesions such as ossifying fibromas (2-4), or cementifying fibromas (5-7) are sometimes present; malignant change of the parathyroid tumor $(1,3,7-9)$ has been reported in several families. Recently, FIHP was suggested to be a clinically and even genetically distinct syndrome from the multiple endocrine neoplasia (MEN) syndrome and from familial hypocalciuric hypercalcemia (10); FIHP is probably related to a dominant oncogene/suppressorgene on chromosome $1(1,2,4,11)$.

We describe three siblings with FIHP. All three cases had multiple parathyroid adenomas and the two females had multiple uterine adenomyomatous polyps; one had the added complication of multiple ossifying jaw fibromas.

\section{Case reports}

\section{Case 1}

In September 1985 a 22-year-old woman noticed swelling of the left cheek and left nasal obstruction. In
October, she began to feel left cheek pain and was admitted to Kyushu Chuo Hospital (Japan). She had also suffered from dysmenorrhea and hypermenorrhea for several years and multiple uterine polyps had been removed in April 1985.

On physical examination, the left cheek was swollen with left exophthalmos. Two nodules about $1.5 \mathrm{~cm}$ in size were palpable at the upper and lower edges of the right thyroid lobe. Lymph nodes were not palpable. There were no abnormal neurological findings.

Laboratory data (Table 1) revealed primary hyperparathyroidism, and there was no evidence of any other endocrinological abnormalities. A cervical echogram showed two hypoechoic smooth tumors at the upper and lower edges of the right thyroid. A computed tomography (CT) scan of the skull (Fig. 1) showed an osteolytic mass with irregular calcifications in the left antrum.

In December 1985 the left antral mass was removed by surgery. Histological examination revealed fibroblasts and collagen fibers proliferating in a storiform or fascicular pattern. Irregular bone trabeculae were present, but giant cells were not. These features led to the diagnosis of 'ossifying fibroma'.

In February 1986 the right upper and lower parathyroid tumors were surgically removed. Both 
Table 1 Pedigree, laboratory data, and complications of the patients.

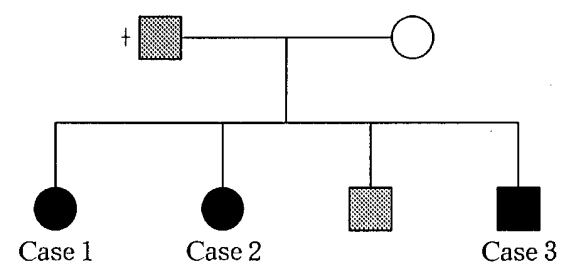

\begin{tabular}{|c|c|c|c|c|}
\hline Parameter & Normal range & Case 1 & Case 2 & Case 3 \\
\hline Calcium (mmol/l) & $2.0-2.5$ & 3.0 & 4.0 & 2.7 \\
\hline Phosphate $(\mathrm{mmol} / \mathrm{l})$ & $0.9-1.4$ & 0.6 & 0.6 & 1.0 \\
\hline Alkaline phosphatase (IU/I) & $75-210$ & 432 & 1630 & 456 \\
\hline Intact-PTH (ng/l) & $10-60$ & & 1146 & 129 \\
\hline HS-PTH $(\mu \mathrm{g} / /)^{*}$ & $150-500$ & & 20000 & 2210 \\
\hline C-PTH $(\mu \mathrm{g} / /)^{* *}$ & $<0.5$ & 1.9 & & \\
\hline Free thyroxine $(\mathrm{pmol} / \mathrm{l})$ & $9-26$ & 14.1 & 10.2 & 18.0 \\
\hline Thyrotropin (mU//) & $0.3-6.5$ & 1.1 & 1.5 & 1.2 \\
\hline Prolactin $(\mu \mathrm{g} / \mathrm{l})$ & $1.5-15$ & 4.4 & 11.0 & 3.0 \\
\hline Growth hormone $(\mu \mathrm{g} / \mathrm{l})$ & $<5.0$ & 0.39 & 0.94 & 0.09 \\
\hline Gastrin (ng/l) & $<200$ & 76 & 97 & 43 \\
\hline Parathyroid tumor & & $\begin{array}{l}\text { Right, upper } \\
\text { (adenoma) } \\
\text { Right, lower } \\
\text { (adenoma) }\end{array}$ & $\begin{array}{l}\text { Right, upper } \\
\text { (cancer?) } \\
\text { Right, lower } \\
\text { (adenoma) }\end{array}$ & $\begin{array}{l}\text { Right, lower } \\
\text { (adenoma) } \\
\text { Left, lower } \\
\text { (adenoma) }\end{array}$ \\
\hline Complication & & $\begin{array}{l}\text { Ossifying fibromas } \\
\text { (left antrum) } \\
\text { (bil. mandible) } \\
\text { Adenomyomatous } \\
\text { polyps (uterus) }\end{array}$ & $\begin{array}{l}\text { Tetany after } \\
\text { aspiration } \\
\text { cytology } \\
\text { Adenomyomatous } \\
\text { polyps (uterus) }\end{array}$ & Urolithiasis \\
\hline
\end{tabular}

${ }^{*} \mathrm{HS}-\mathrm{PTH}$, high-sensitive midregion of parathyroid hormone; ${ }^{* \star} \mathrm{C}-\mathrm{PTH}, \mathrm{C}$-terminal portion of parathyroid hormone; bil., bilateral. Squares, males; circles, females; shaded squares, males with urolithiasis.

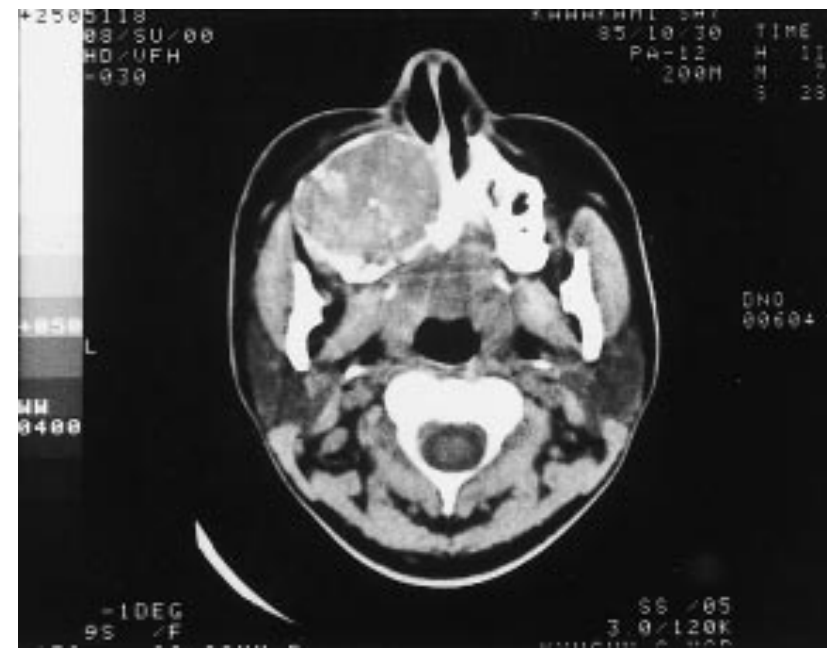

Figure 1 The CT scan of the skull in case 1 shows an osteolytic mass with irregular calcifications in the left antrum. were eosinophilic parathyroid adenomas. After parathyroidectomy, transient tetany occurred, requiring administration of activated vitamin $\mathrm{D}$ for eight months. Thereafter, the serum calcium and PTH levels returned to normal.

In summer 1986 the patient noticed swelling of the right mandible. In 1987 her mandible was bilaterally swollen; CT scan of the lower jaw revealed bilateral mandibular tumors, which were removed by surgery in August. Both of the tumors were also ossifying fibromas.

In 1990 the patient complained of hypermenorrhea and dozens of small uterine polyps were again noticed. Uterine polyps were removed by curettage, which was repeated in 1991 and 1993. These polyps consisted of hyperplastic endometrial glands and dense stroma rich in smooth muscle cells.

\section{Case 2}

In September 1992 a younger sister of patient 1, 29 years old, complained of general fatigue. On physical examination, a neck nodule and hypercalcemia were observed. In February 1993 she began to suffer from 
headache, thirst, polyuria and polyarthralgia. She was referred to the Second Department of Internal Medicine, Kyushu University Hospital, in March 1993.

This patient, also, had suffered from hypermenorrhea for several years and dozens of small nodules were noted in the uterus in 1991. These nodules were removed in 1993; they consisted of endometrial glands and dense stroma rich in smooth muscle fibers. Adenomyomatous polyps were diagnosed.

On physical examination, a hard nodule was palpable in the right anterior neck. Lymph nodes were not palpable. There were no abnormal neurological findings.

Laboratory data (Table 1) revealed primary hyperparathyroidism without any other endocrinological abnormalities. A cervical echogram showed two hypoechoic tumors; one was in the middle-posterior part of the right lobe of the thyroid, $2.0 \mathrm{~cm}$ in size, with irregular echo-pattern, and the other was at the lower edge of the right thyroid, $0.8 \mathrm{~cm}$ in size. No lymph node swelling was noticed.

In order to determine the origin of the bigger tumor, fine-needle aspiration cytology was performed. The aspirates showed clusters of atypical cells. The highsensitive (HS)-PTH level (using a radioimmunoassay for the mid-region of PTH, Yamasa Shoyu Co., Tokyo, Japan) measured from the wash-water of the needle was extremely high: $134000 \mu \mathrm{g} / \mathrm{l}$ (normal range in the serum $150-500 \mu \mathrm{g} / \mathrm{l}$ ). Therefore, the bigger tumor seemed to be of parathyroid origin and was possibly malignant.

Two days after the aspiration cytology, the patient complained of numbness of the tongue and of general fatigue. After six days, Chvostek sign and Trousseau sign were noticed, and the serum calcium level markedly decreased to $1.7 \mathrm{mmol} / \mathrm{l}$. The serum HS-PTH level was also decreased from 20000 to $3100 \mu \mathrm{g} / \mathrm{l}$, although the level remained higher than normal.

After 18 days, these two tumors, the right lobe of the thyroid, and cervical lymph nodes were removed by surgery. The bigger tumor was encapsulated by thick fibrous connective tissue and its center was replaced by necrotic tissue. Small clusters of atypical cells showing hyperchromatic nuclei and eosinophilic cytoplasm were seen at the periphery of the necrotic lesion, but it was difficult to make a histological diagnosis. The other tumor was an eosinophilic parathyroid adenoma. There was no sign of metastasis in the lymph nodes.

\section{Case 3}

In October 1993 a younger brother of patients 1 and 2, 17 years old, was referred to the Second Department of Internal Medicine, Kyushu University Hospital, having been diagnosed as having urolithiasis and hypercalcemia.

A nodule was palpable near the lower edge of the right thyroid. Lymph nodes were not palpable. Laboratory data (Table 1) suggested primary hyperparathyroidism. A cervical echogram showed a hypoechoic tumor,
$1.0 \mathrm{~cm}$ in size, at the lower edge of the right thyroid. The tumor was surgically removed and found to be an eosinophilic parathyroid adenoma. The patient became normocalcemic after a transient episode of tetany.

In August 1996 the patient was again diagnosed as having hypercalcemia $(2.7 \mathrm{mmol} / \mathrm{l})$ with elevated serum intact-PTH levels $(170 \mathrm{ng} / \mathrm{l})$, and another tumor, $1.0 \mathrm{~cm}$ in size, was noticed at the lower part of the left thyroid. This tumor, also, was removed and found to be a parathyroid adenoma.

In these three cases, imaging studies such as abdominal echogram and CT showed no sign of any other endocrine tumors except for the parathyroid lesions. The remaining sibling, their brother, had a history of urolithiasis. However, his serum calcium and intact-PTH levels were in the normal range (serum calcium $2.5 \mathrm{mmol} / \mathrm{l}$, intact-PTH $47 \mathrm{ng} / \mathrm{l}$ ) and a cervical echogram did not reveal any evidence of parathyroid adenoma in April 1997. Their father, who had died of renal failure 17 years before at the age of 49 , had also had urolithiasis and hypertension, but it was not known whether he had had hypercalcemia. He had two brothers who died young but the details were unclear. The patients' mother is healthy and normocalcemic. There is no record suggesting hypercalcemia or urolithiasis among her nine siblings.

\section{Discussion}

The characteristic findings in this family are as follows: (i) familial hyperparathyroidism was found in three of four siblings examined, (ii) parathyroid adenomas were multiple in all three, (iii) multiple ossifying jaw fibromas were found in case 1, (iv) unusual multiple small adenomyomatous polyps of the uterus were found in cases 1 and 2, and (v) tetany occurred in case 2 after aspiration cytology of the tumor.

MEN (types 1 and 2) is a well known clinical entity complicated by other endocrinopathies including pituitary, thyroid, adrenal gland, and pancreatic island. Hyperplasia of the parathyroid gland is usually found in almost all cases of MEN-1 (12). In our cases, however, no endocrinopathies except for the parathyroid gland were found; these parathyroid tumors were adenomas.

Familial hyperparathyroidism without other endocrinological abnormalities has been called FIHP. In some cases, 'FIHP' may be an allelic variant of MEN-1. Parathyroid disease is usually the first manifestation in MEN-1 and a long-term follow-up is needed to identify other endocrine lesions, mainly in the pancreas or pituitary. This observation could explain the data of Kassem et al. (13) suggesting that some cases of FIHP are linked to chromosome 11q13, possibly the MEN-1 locus. However, many FIHP families have shown unique clinical features: (i) frequently observed jaw tumors such as ossifying fibromas or cementifying fibromas $(2-7)$, and (ii) a high prevalence of parathyroid adenomas $(2-8,14-20)$ and carcinomas (1, 3, 7-9). 
Table 2 Reported cases of familial isolated hyperparathyroidism with various complications.

\begin{tabular}{|c|c|c|c|}
\hline Reference & $\begin{array}{c}\text { Number of } \\
\text { affected members }\end{array}$ & $\begin{array}{l}\text { Pathology of } \\
\text { parathyroid glands } \\
\text { (no. of cases) }\end{array}$ & $\begin{array}{l}\text { Complications in } \\
\text { affected members* } \\
\text { (no. of cases) }\end{array}$ \\
\hline Kennett \& Pollick (14) & $2(\mathrm{M} 1, \mathrm{~F} 1)$ & Adenoma (2) & $\begin{array}{l}\text { Osteitis fibrosa cystica (jaw) } \\
\text { Ossifying fibroma? (jaw) }\end{array}$ \\
\hline Marsden et al. (15) & $6(\mathrm{M} 5, \mathrm{~F} 1)$ & Adenoma (6) & \\
\hline $\begin{array}{l}\text { Shimura et al. (16) } \\
\text { Akagi et al. (17) }\end{array}$ & $3(\mathrm{M} 1, \mathrm{~F} 2)$ & Adenoma (3) & Thyroid adenoma \\
\hline Dinnen et al. (3) & $\begin{array}{l}5(\mathrm{M} 4, \mathrm{~F} 1) \\
2(\mathrm{M} 1, \mathrm{~F} 1)\end{array}$ & $\begin{array}{l}\text { Adenoma (2) } \\
\text { Carcinoma (1) } \\
\text { Adenoma (1) } \\
\text { Carcinoma (1) }\end{array}$ & $\begin{array}{l}\text { Dental cyst? Jaw tumor } \\
\text { Ichthyosis } \\
\text { Ossifying fibroma (jaw) (2) }\end{array}$ \\
\hline Rosen \& Palmer (9) & $2(\mathrm{M} 1, \mathrm{~F} 1)$ & $\begin{array}{l}\text { Hyperplasia (2) } \\
\text { Carcinoma (1) }\end{array}$ & $\begin{array}{l}\text { Non-ossifying fibroma (jaw) (2) } \\
\text { Fibrous dysplasia (jaw) (2) }\end{array}$ \\
\hline Allo \& Thompson (18) & $4(\mathrm{M} 2, \mathrm{~F} 2)$ & Adenoma (4) & \\
\hline Warnakulasuriya et al. (5) & $2(\mathrm{M} 2, \mathrm{~F} 0)$ & Adenoma (2) & Cementifying fibroma (jaw) (2) \\
\hline Mallette et al. (19) & $4(\mathrm{M} 4, \mathrm{~F} 0)$ & Adenoma (4) & Jaw tumor $(3)$ \\
\hline Feig \& Gottesman (21) & $2(\mathrm{M} 2, \mathrm{~F} 0)$ & Hyperplasia (2) & Colonic carcinoma (2) \\
\hline Jackson et al. (2) & $12(\mathrm{M} 7, \mathrm{~F} 5)$ & Adenoma (12) & Ossifying fibroma (jaw) (6) \\
\hline Streeten et al. (8) & 5 (M2, F3) & $\begin{array}{l}\text { Adenoma (2) } \\
\text { Carcinoma (2) }\end{array}$ & Pituitary cyst \\
\hline Sandler \& Moncrieff (20) & $2(\mathrm{M} 1, \mathrm{~F} 1)$ & Adenoma (2) & Thyrotoxicosis \\
\hline Wassif et al. (1) & $12(\mathrm{M} 9, \mathrm{~F} 3)$ & Carcinoma (1) & \\
\hline Kassem et al. (13) & 14 (M6, F8) & $\begin{array}{l}\text { Hyperplasia (8) } \\
\text { Adenoma (1) }\end{array}$ & \\
\hline Kakinuma et al. (7) & $3(\mathrm{M} 0, \mathrm{~F} 3)$ & $\begin{array}{l}\text { Adenoma (2) } \\
\text { Carcinoma (1) }\end{array}$ & $\begin{array}{l}\text { Cementifying fibroma (jaw) } \\
\text { Wilm's tumor, uterine myoma }\end{array}$ \\
\hline Inoue et al. (6) & $2(\mathrm{M} 1, \mathrm{~F} 1)$ & $\begin{array}{l}\text { Hyperplasia (1) } \\
\text { Adenoma (1) }\end{array}$ & $\begin{array}{l}\text { Cementifying fibroma (jaw) } \\
\text { Thyroid carcinoma } \\
\text { Uterine myoma, endometriosis }\end{array}$ \\
\hline Teh et al. (4) & $\begin{array}{l}4(\mathrm{M} 3, \mathrm{~F} 1) \\
4(\mathrm{M} 4, \mathrm{~F} 0)\end{array}$ & $\begin{array}{l}\text { Hyperplasia (1) } \\
\text { Adenoma (1) } \\
\text { Adenoma (1) }\end{array}$ & $\begin{array}{l}\text { Ossifying fibroma (jaw) (2) } \\
\text { Renal hamartoma (2), renal cysts (3) } \\
\text { Ossifying fibroma? (jaw) } \\
\text { Jaw tumor, renal cysts (2) }\end{array}$ \\
\hline
\end{tabular}

${ }^{*}$ Complications associated with hyperparathyroidism such as urolithiasis, pathological fracture, renal failure, peptic ulcer, pancreatitis, and brown tumor are not included.

$M$, male; $F$, female.

Reported families with FIHP and various complications in the affected members are shown in Table 2 $(1-9,13-21)$. Fifty-six men and thirty-four women in nineteen families were reported; the male/female ratio was 1.6. Mean onset age was 33 years. In 8 families, hyperparathyroidism appeared in 3-5 siblings. The majority of the reported parathyroid tumors were adenomas. Although sporadic cases with multiple adenomas had been reported in 1 or 2 patients in 6 families $(1,2,5,8,15,19)$, the family reported here is unique because all three affected siblings had multiple adenomas. Since multiple parathyroid adenomas are rare in the general population, this family supported the genetic origin of the disease. Parathyroid carcinomas were reported in 6 of the 19 families $(1,3,7-9)$. Jaw tumor is the most common complication of FIHP (2-7, 9,14 ) and other tumors in the thyroid, colon, kidney, or uterus have been reported.

Wassif et al. (1) and Jackson et al. (2) reported lack of genetic linkage between FIHP and MEN (types 1 and 2). Recently, Szabo et al. (11) reported that HRPT2, an endocrine tumor gene on the long arm of chromosome
1 (1q21-q31), was responsible for the syndrome of FIHP and jaw tumors. Linkage to this chromosomal region was also reported in two FIHP families by Teh et al. (4). The genetic association between FIHP and Wilms' tumor has also been discussed by Kakinuma et al. (7). Uterine myoma was reported in two families $(6,7)$; however, multiple adenomyomatous polyps of the uterus associated with FIHP as shown in our cases have not been reported.

Adenomyomatous polyp of the uterus is a rare, non hereditary, usually solitary polypoid lesion, composed of endometrial glands admixed with smooth muscle cells $(22,23)$. In our two female cases, however, these polyps were multiple, familial, and associated with FIHP. Although it is still unclear whether adenomyomatous polyps of the uterus are a variant of adenomyosis or of endometriosis or are truly neoplastic, there might be some genetical relation with FIHP.

Parathyroid lesions tend to be malignant in FIHP (1, 3, 7-9). Although Smith \& Coombs (24) reported the histological features of malignant changes, the histological diagnosis of parathyroid carcinoma is 
difficult. In parathyroid cancers, the tumors are usually bigger, harder, and easily palpable with higher serum calcium levels of more than $3.5 \mathrm{mmol} / \mathrm{l}$, and PTH levels more than 3-4 times as high as normal (25). In case 2 , the bigger tumor had these features and aspiration cytology revealed many atypical cells, but the final diagnosis must await eventual histological examination.

The most dramatic incident in case 2 was the occurrence of tetany two days after aspiration cytology. Parathyroid tumors are liable to undergo infarction as the result of palpation or angiography (26). Therefore, it is likely that the aspiration procedure provoked the infarction and necrosis of the tumor.

Histological examination of the bigger nodule in case 2 revealed only necrotic tissue without any evidence of malignancy. After a follow-up period of more than two years, there has been no evidence of recurrence or of metastasis of the parathyroid carcinoma. Careful long-term follow up is required because metastasis of parathyroid carcinoma occurring as long as 15 years after the resection of a parathyroid 'adenoma' has been reported (27).

In conclusion, we have reported a family with FIHP with ossifying fibroma. Multiple parathyroid adenomas found in all three siblings and multiple uterine adenomyomatous polyps found in the two female patients suggested the genetic origin of the disease affecting multiple organs.

\section{References}

1 Wassif WS, Moniz CF, Friedman E, Wong S, Weber G, Nordenskjold $\mathrm{M}$ et al. Familial isolated hyperparathyroidism: a distinct genetic entity with an increased risk of parathyroid cancer. Journal of Clinical Endocrinology and Metabolism 199377 1485-1489.

2 Jackson CE, Norum RA, Boyd SB, Talpos GB, Wilson SD, Taggart RT et al. Hereditary hyperparathyroidism and multiple ossifying jaw fibromas. Surgery 1990108 1006-1013.

3 Dinnen JS, Greenwood RH, Jones LH, Walker DA \& Williams ED. Parathyroid carcinoma in familial hyperparathyroidism. Journal of Clinical Pathology 197730 966-975.

4 Teh BT, Farnebo F, Kristoffersson U, Sundelin B, Cardinal J, Axelson R et al. Autosomal dominant primary hyperparathyroidism and jaw tumor syndrome associated with renal hamartomas and cystic kidney disease: linkage to 1q21-q32 and loss of the wild type allele in renal hamartomas. Journal of Clinical Endocrinology and Metabolism 199681 4204-4211.

5 Warnakulasuriya S, Markwell BD \& Williams DM. Familial hyperparathyroidism associated with cementifying fibromas of the jaws in two siblings. Oral Surgery Oral Medicine Oral Pathology $198559269-274$

6 Inoue H, Miki H, Oshimo K, Tanaka K, Monden Y, Yamamoto A et al. Familial hyperparathyroidism associated with jaw fibroma: case report and literature review. Clinical Endocrinology 199543 225-229.
7 Kakinuma A, Morimoto I, Nakano Y, Fujimoto R, Ishida O, Okada Y et al. Familial primary hyperparathyroidism complicated with Wilms' tumor. Internal Medicine 199433 123-126.

8 Streeten EA, Weinstein LS, Norton JA, Mulvihill JJ, White BJ, Friedman E et al. Studies in kindred with parathyroid carcinoma. Journal of Clinical Endocrinology and Metabolism 199275 362-366.

9 Rosen IB \& Palmer JA. Fibroosseous tumors of the facial skeleton in association with primary hyperparathyroidism: an endocrine syndrome or coincidence? American Journal of Surgery 1981142 494-498.

10 Pollak MR, Brown EM, Chou Y-HW, Hebert SC, Marx SJ, Steinmann $\mathrm{B}$ et al. Mutations in the human $\mathrm{Ca}^{2+}$-sensing receptor gene cause familial hypocalciuric hypercalcemia and neonatal hyperparathyroidism. Cell 199375 1297-1303.

11 Szabo J, Heath B, Hill VM, Jackson CE, Zarbo RJ, Mallette LE et al. Hereditary hyperparathyroidism-jaw tumor syndrome: the endocrine tumor gene HRPT2 maps to chromosome 1q21-q31. American Journal of Human Genetics 199556 944-950.

12 Rizzoli R, Green J III \& Marx SJ. Primary hyperparathyroidism in familial multiple endocrine neoplasia type I. American Journal of Medicine 198578 467-474.

13 Kassem M, Zhang X, Brask S, Eriksen EF, Mosekilde L \& Kruse TA. Familial isolated primary hyperparathyroidism. Clinical Endocrinology 199441 415-420.

14 Kennett S \& Pollick H. Jaw lesions in familial hyperparathyroidism. Oral Surgery Oral Medicine Oral Pathology 197131 502-510.

15 Marsden P, Anderson J, Doyle D, Morris BA \& Burns DA. Familial hyperparathyroidism. British Medical Journal 19713 87-93.

16 Shimura H, Mihara A \& Hashizume Y. Familial hyperparathyroidism. Nihon Rinshou 197280 838-844 (in Japanese).

17 Akagi K, Iida H, Nakajima T, Fujishima M \& Omae T. Familial hyperparathyroidism. Journal of Japanese Society of Internal Medicine 197362 47-53 (in Japanese).

18 Allo M \& Thompson NW. Familial hyperparathyroidism caused by solitary adenomas. Surgery 198292 486-490.

19 Mallette LE, Malini S, Rappaport MP \& Kirkland JL. Familial cystic parathyroid adenomatosis. Annals of Internal Medicine 1987107 54-60.

20 Sandler LM \& Moncrieff MW. Familial hyperparathyroidism. Archives of Diseases in Childhood 198055 146-157.

21 Feig DS \& Gottesman IS. Familial hyperparathyroidism in association with colonic carcinoma. Cancer 198760 429-432.

22 Nasu K, Sugano T \& Miyakawa I. Adenomyomatous polyp of the uterus. International Journal of Gynaecology and Obstetrics 1995 48 319-321.

23 Silverberg SG. Adenomyomatosis of endometrium and endocervix - a hamartoma? American Journal of Clinical Pathology 197564 192-199.

24 Smith JF \& Coombs RRH. Histological diagnosis of carcinoma of the parathyroid gland. Journal of Clinical Pathology 198437 $1370-1378$

25 Fujimoto $\mathrm{Y} \&$ Obata T. How to recognize and treat parathyroid carcinoma. Surgical Clinics of North America 198767 343-357.

26 Doppman JL, Brown EM, Brennan MF, Spiegel A, Marx SJ \& Aurbach GD. Angiographic ablation of parathyroid adenoma. Radiology $1975130577-582$.

27 Ebner S \& Emerson CH. Documentation of parathyroid carcinoma fifteen years after resection of a parathyroid 'adenoma'. Clinical Endocrinology 199338 659-661.

Received 30 June 1997

Accepted 26 January 1998 